\title{
A study on biological activity of marine fungi from different habitats in coastal regions
}

\author{
Songlin Zhou ${ }^{1}$, Min Wang ${ }^{1}$, Qi Feng ${ }^{2 *}$, Yingying Lin ${ }^{1}$ and Huange Zhao ${ }^{1}$
}

\begin{abstract}
In recent years, marine fungi have become an important source of active marine natural products. Former researches are limited in habitats selection of fungi with bioactive compounds. In this paper were to measure antibacterial and antitumor cell activity for secondary metabolites of marine fungi, which were isolated from different habitats in coastal regions. 195 strains of marine fungi were isolated and purified from three different habitats. They biologically active experiment results showed that fungi isolation from the mangrove habitats had stronger antibacterial activity than others, and the stains isolated from the estuarial habitats had the least antibacterial activity. However, the strains separated from beach habitats strongly inhibited tumor cell proliferation in vitro, and fungi of mangrove forest habitats had the weakest activity of inhibiting tumor. Meanwhile, 195 fungal strains belonged to 46 families, 84 genera, 142 species and also showed 137 different types of activity combinations by analyzing the inhibitory activity of the metabolites fungi for 4 strains of pathogenic bacteria and B-16 cells. The study investigated the biological activity of marine fungi isolated from different habitats in Haikou coastal regions. The results help us to understand bioactive metabolites of marine fungi from different habitats, and how to selected biological activity fungi from various marine habitats effectively.
\end{abstract}

Keywords: Marine fungus, Habitats, Diversity, Biological activity

\section{Background}

Marine habitats can be categorized into two types: coastal region habitats, deep-sea region habitats (Richards et al. 2012). Coastal regions are characterized by eutrophication from terrestrial run-off and high primary production, on the other hand this leads to large availability of organic matter to consumers as detritus (Danovaro and Pusceddu 2007). Marine fungi are known to play an important role as primary degraders in coastal waters (Massana and Logares 2013). Due to the long coastal line, therefore, a lot of unique niches were found such as the coral reef habitats, the mangrove habitats, estuarine habitats, beach habitats, rocky habitats etc.(Richards et al. 2012; Rämä et al. 2014). There are many reports either focusing on the use of molecular techniques or the traditional taxonomic methods to investigate microbial

\footnotetext{
*Correspondence: 26540760@qq.com

2 Department of Aquatic Science and Technology, Jiangsu Agri-animal

Husbandry Vocational College, Taizhou 225300, China

Full list of author information is available at the end of the article
}

diversity from marine environments (Miloslavich et al. 2010; Singh et al. 2012; Klindworth et al. 2014), or reports researching marine fungi isolated from all kinds of new compounds with various biological activities in different habitats (Blunt et al. 2014). However, few studies reported the active marine fungi interrelation between the biological activity of metabolites and separate from habitats. In this study we examined the antibacterial and antitumor activity of fungi isolated from three different coastal niches, which can not only enriched the diversity of marine fungus, but also helped select antibacterial or anti-tumor active strains.

Haikou is located in the tropical northern margin of low latitude, which has a tropical oceanic monsoon climate. Coastal areas have several niches, such as beach habitats, rocky shoreline habitats, mangrove habitats. These habitats were selected for which may display extreme abundance in microbial biodiversity. 


\section{Methods}

\section{Cell lines and pathogenic bacteria}

B16 Melanoma cells, Staphlococcus aureus ATCC25923, Pseudomonas aeruginosa ATCC 27853, Klebsiella pneumoniae ATCC700603 and Escherichia coli ATCC 25922 were provided by the National Institute for the Control of Pharmaceutical and Biological Products (Beijing, China).

\section{Sites and sample collection}

Seawater, sediments and rotted leaves were collected from three coastal marine habitats (beach habitats of west coastal Haikou, estuarine habitats of Nan Dujiang River, and mangrove habitats of YanFeng town) in Haikou during March, 2012 (Fig. 1 and Table 1). These samples were carried in sterile, screw capped plastic bottles. The isolation of fungi from the seawater samples was finished using the membrane filtration technique within one hour after collection. $15 \mathrm{ml}$ water samples were filtered through sterile $0.45 \mu \mathrm{m}$ in cellulose ester membranes. These membranes were then placed on the ordinary separation medium (Glucose $10 \mathrm{~g} / \mathrm{L}$, peptone $2 \mathrm{~g} / \mathrm{L}$, yeast extract $1 \mathrm{~g} / \mathrm{L}$, agar $20 \mathrm{~g} / \mathrm{L}$, streptomycin $75 \mathrm{mg} / \mathrm{L}$, ampicillin $50 \mathrm{mg} / \mathrm{L}$, aged seawater $600 \mathrm{~mL} / \mathrm{L})$. Sediment samples $(0.1 \mathrm{~g})$ were suspended in $10 \mathrm{ml}$ sterile seawater and $100 \mu \mathrm{l}$ of the resulting suspension was plated directly on the ordinary separation medium.

Rotted leaves were washed thoroughly three times with sterile distilled water, surface sterilized with $5 \%$

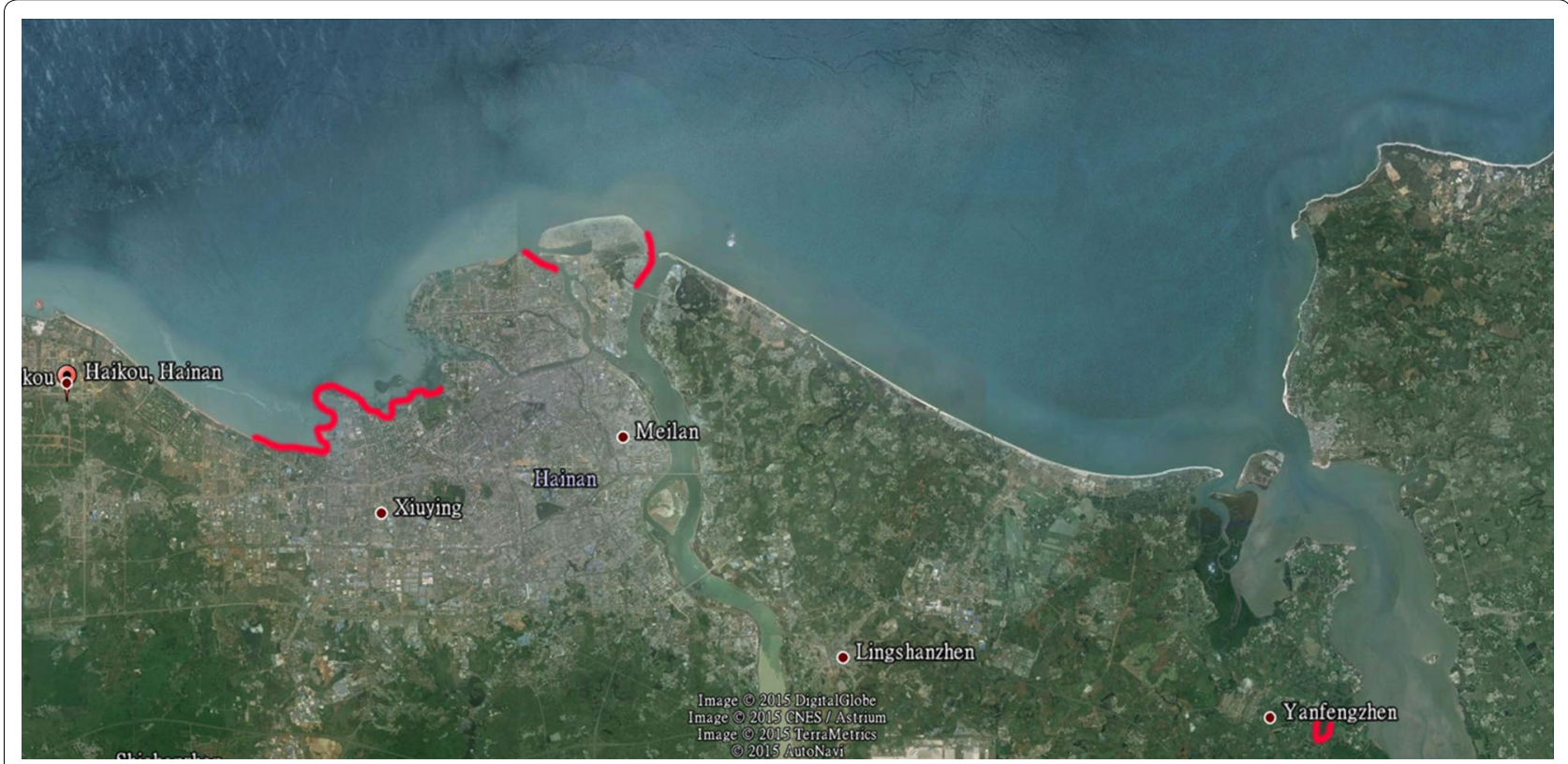

Fig. 1 Red tag areas indicated the location of sample sites

Table 1 Details regarding the sample types and geographical distribution and isolated fungal colonies

\begin{tabular}{|c|c|c|c|c|c|c|c|c|c|}
\hline $\begin{array}{l}\text { Sampling } \\
\text { date }\end{array}$ & Location & Lat $\left({ }^{\circ} \mathrm{N}\right)$ & Long $\left({ }^{\circ} \mathrm{E}\right)$ & Habitat & Depth (m) & $\begin{array}{l}\text { Tempera- } \\
\text { ture }\left({ }^{\circ} \mathrm{C}\right)\end{array}$ & $\begin{array}{l}\text { Salinity } \\
\text { (ppt) }\end{array}$ & $\begin{array}{l}\text { No. } \\
\text { of sam- } \\
\text { ples }\end{array}$ & $\begin{array}{l}\text { No. } \\
\text { of stains }\end{array}$ \\
\hline \multirow{3}{*}{$2012-3-18$} & \multirow{3}{*}{$\begin{array}{l}\text { West Coastal of } \\
\text { Haikou }\end{array}$} & \multirow{3}{*}{$20^{\circ} 1^{\prime} 53^{\prime \prime}-1^{\prime} 3^{\prime \prime}$} & \multirow{3}{*}{$\begin{array}{c}110^{\circ} 18^{\prime} 17^{\prime \prime}- \\
14^{\prime} 23^{\prime \prime}\end{array}$} & Seawater & 0 & 21.7 & 31.7 & 7 & 13 \\
\hline & & & & Sediments & 0 & 21.7 & 31.7 & 7 & 11 \\
\hline & & & & Rotted leaves & 0 & 21.7 & 31.7 & 30 & 82 \\
\hline \multirow[t]{3}{*}{$2012-3-22$} & \multirow{3}{*}{$\begin{array}{l}\text { Nan Dujiang } \\
\text { River }\end{array}$} & \multirow{3}{*}{$\begin{array}{l}20^{\circ} 4^{\prime} 48^{\prime \prime}-4^{\prime} 2^{\prime \prime} \\
20^{\circ} 4^{\prime} 36^{\prime \prime}-4^{\prime} 21^{\prime \prime}\end{array}$} & \multirow{3}{*}{$\begin{array}{c}110^{\circ} 22^{\prime} 43^{\prime \prime}- \\
22^{\prime} 30^{\prime \prime} \\
110^{\circ} 20^{\prime} 26^{\prime \prime}- \\
20^{\prime} 56^{\prime \prime}\end{array}$} & Seawater & 0 & 23.3 & $20.1 \sim 23.5$ & 5 & 8 \\
\hline & & & & Sediments & 0 & 23.3 & $20.1 \sim 23.5$ & 5 & 5 \\
\hline & & & & Rotted leaves & 0 & 23.3 & $20.1 \sim 23.5$ & 10 & 23 \\
\hline \multirow[t]{3}{*}{$2012-3-28$} & \multirow{3}{*}{$\begin{array}{l}\text { Yan Feng Man- } \\
\text { grove }\end{array}$} & \multirow[t]{3}{*}{$19^{\circ} 57^{\prime} 1^{\prime \prime}-57^{\prime} 11^{\prime \prime}$} & \multirow{3}{*}{$\begin{array}{l}110^{\circ} 34^{\prime} 53^{\prime \prime}- \\
35^{\prime} 27\end{array}$} & Seawater & 0 & 20.6 & 19.6 & 4 & 8 \\
\hline & & & & Sediments & 0 & 20.6 & 19.6 & 4 & 7 \\
\hline & & & & Rotted leaves & 0 & 20.6 & 19.6 & 12 & 38 \\
\hline
\end{tabular}


$\mathrm{NaClO}$ for $5 \mathrm{~min}, 75 \%$ ethanol for $1 \mathrm{~min}$, and sterile distilled water twice. Each sample was then cut into $4 \mathrm{~mm}$ to $6 \mathrm{~mm}$ sections and placed on ordinary separation medium plates. All plates were incubated at $25{ }^{\circ} \mathrm{C}$ and examined daily for the growth of fungi. Fungal colonies that developed were sub-cultured onto fresh ordinary separation medium plate for pure, single colony isolation and identification. The identification of filamentous fungi was done by macroscopic and microscopic morphology.

\section{DNA extraction, amplification and sequencing}

The chromosomal DNA from all strains were extracted using a fungus genomic DNA extraction kit (Tiangen Co., China), and the isolated DNA was amplified by PCR using universal primers ITS 1 and ITS 4 (Rivera and Seifert 2011), corresponding to a 5.8S rDNA sequence. For $\mathrm{PCR}$, the reaction elements included $1 \mu \mathrm{L}$ of the template DNA, $5 \mu \mathrm{L}$ of $10 \times$ Taq buffer, $1 \mu \mathrm{L}$ of $10 \mathrm{mM}$ mixed dNTP, $1 \mu \mathrm{L}$ of sense-ITS 1 primer (TCCGTAGGTGAACCTGCGG, $10 \mathrm{pmol} / \mu \mathrm{L}), 1 \mu \mathrm{L}$ of antisense-ITS 4 primer (TCCTCCGCTTATTGATATGC, $10 \mathrm{pmol} / \mu \mathrm{L}$ ), and $5 \mathrm{U}$ of Taq DNA polymerase, which were prepared in a final volume of $50 \mu \mathrm{L}$. The PCR thermal conditions were set as follows: preheating for denaturation at $94{ }^{\circ} \mathrm{C}$ for $4 \mathrm{~min}, 30$ cycles of denaturation at $94{ }^{\circ} \mathrm{C}$ for $30 \mathrm{~s}$, annealing at $52^{\circ} \mathrm{C}$ for $30 \mathrm{~s}$, extension at $72{ }^{\circ} \mathrm{C}$ for $60 \mathrm{~s}$, and additional extension at $72{ }^{\circ} \mathrm{C}$ for $7 \mathrm{~min}$. The PCR products were purified using Gel DNA extraction kit (NewTopBio, China). The sequencing analysis data obtained from Sinogenomax Co., Ltd. to blasting other sequences from GenBank comprising with identity sequences.

\section{Phylogenetic analyses}

Forward and reverse sequences were edited and assembled using Chromas Pro version 1.34 (Technelysium Pty Ltd, Tewantia, Queensland, Australia). The final sequences were compared to the nucleotide sequences of reference organisms available in the GenBank database using Blastn. The ITS1-5.8S-ITS4 gene sequences obtained for the organisms were aligned with their closest match using the program ClustalW2. Gaps and ambiguously aligned sequences were removed manually from further analyses. Phylogenetic analyses were carried out using distance setting (Maximum parsimony) in MEGA 5 software with 1000 bootstrap replicates.

\section{Preparation of marine Fungal Extract}

Each fungus was inoculated into a $500 \mathrm{~mL}$ Erlenmeyer flask containing $100 \mathrm{~mL}$ of liquid culture medium (which is general separation medium without penicillin and kalamycin). All shake flasks were incubated on a rotary shaker at $150 \mathrm{rpm}, 25^{\circ} \mathrm{C}$ for $20 \mathrm{~d}$. Each fungal broth was separated into mycelia mat and culture filtrate by Whatman No. 1 filter paper. The mycelia mat was dried and grinded then extracted twice with acetone by ultrasonic condition. Subsequently, the filtrate was evaporated under reduced pressure $\left(8 \times 10^{3} \mathrm{~Pa}\right)$ to yield an extract and then extracted twice with acetone. Then merged all acetone soln. was concentrated to afford a crude extract.

\section{MTT assay}

B-16 cell lines were grown in RPMI-1640 supplemented with 10\% FBS (fetal bovine serum) in a humidified incubator at $37{ }^{\circ} \mathrm{C}$ with $5 \% \mathrm{CO} 2$. Cell suspensions $(190 \mu \mathrm{L}$, $5 \times 10^{4} \mathrm{cell} / \mathrm{mL}$ ) were plated in 96-well microtiter plates and incubated for $18 \mathrm{~h}$. Then, different concentrations of the fungal metabolite extracts were added to each well and further incubated for $48 \mathrm{~h}$. Then the MTT solution $(20 \mu \mathrm{L} ; 5 \mathrm{mg} / \mathrm{mL})$ was added to each well and incubated for $4 \mathrm{~h}$. Old medium containing MTT was then gently replaced by DMSO $(150 \mu \mathrm{L})$ and pipetted to dissolve any formazan crystals formed. Absorbance was then determined at $540 \mathrm{~nm}$ with a Spectra-Max-Plus plate reader.

\section{Antimicrobial test}

Antimicrobial activity of the secondary metabolites from marine microorganisms was carried out by the $\mathrm{K}-\mathrm{B}$ disk diffusion method (Drew et al. 1972). $0.2 \mathrm{~mL}$ of test bacterial solution, which was activated and diluted to $1 / 2$ Mcfar turbidity, was evenly coated and inoculated in sterile Luria-Bertani (LB) broth agar, the drug disks $(50 \mu \mathrm{g})$ were pasted on the inoculated agar plate, with four equidistant disks per plate, but one of them contained no drugs, and each test had 3 parallels. They were inverted in culture incubator at $37{ }^{\circ} \mathrm{C}$ and taken out after $18 \mathrm{~h}$, the diameter of each inhibition zone was measured with vernier caliper, all assays was measured three times and averaged $(\mathrm{n}=3)$.

\section{Statistical analysis}

One objective of this research was to identify various groups of fungi according to their habitats and biological activity, and therefore the two step cluster analysis was performed using SPSS 22.0 (Fig. 2). Before data analysis, the raw data were transformed. Three habitats were denoted by numbers (Beach habitats-1, Estuarine habitats-2, Mangrove habitats-3). The inhibitory effects were converted to numbers (“-" 0 , “+" 1 , “ ++ " 2 , “+++" 3 ) and then transformed into $\mathrm{Z}$ scores. In cluster analysis, habitats were selected as categorical variables, the inhibitory effects against different bacterial strains and tumor cells were classified into continuous variables. After that, the frequency of different combination of inhibitory effects was described with Excel data explorer using transformed data. 


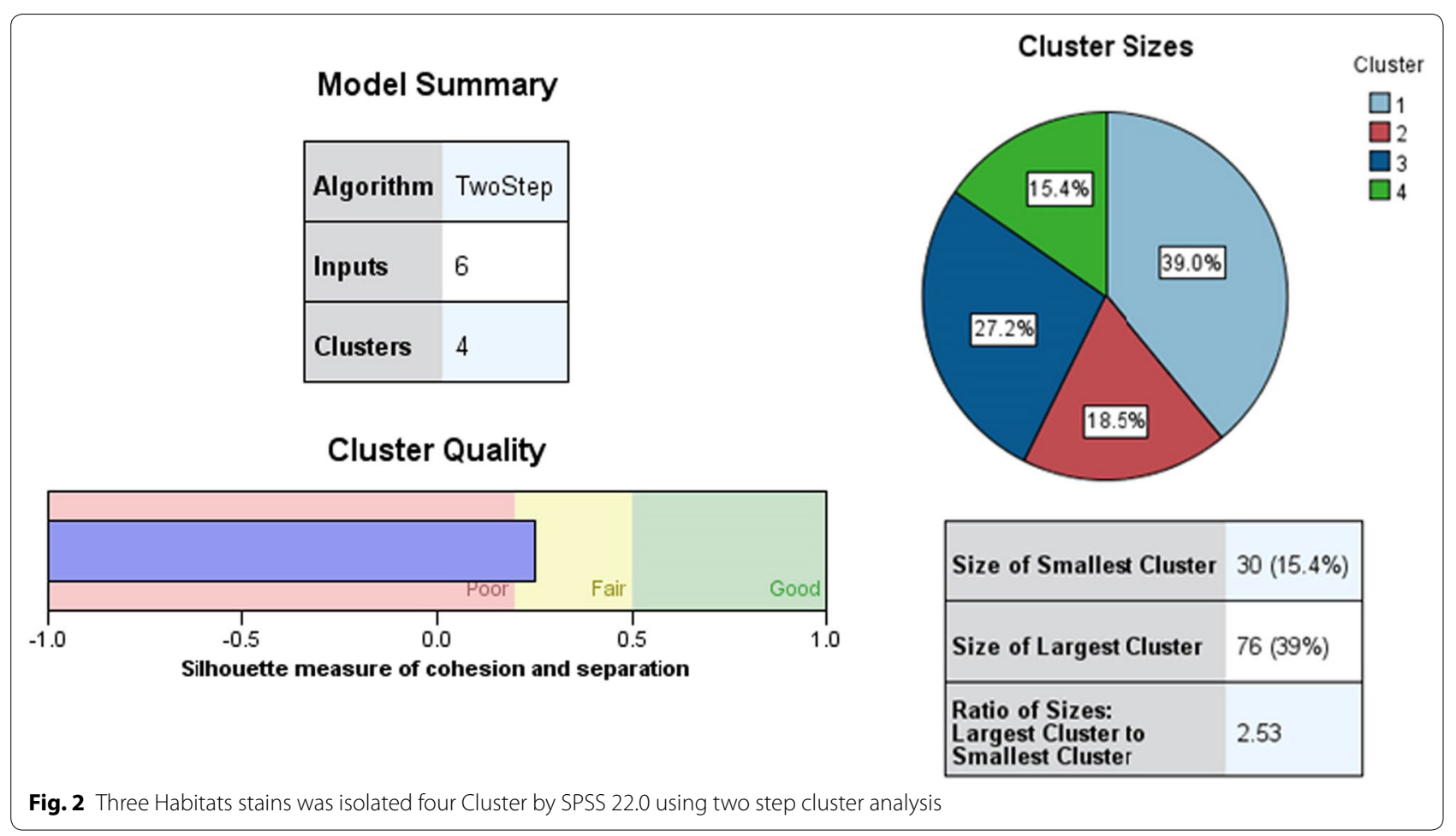

\section{Results}

\section{Culturable diversity}

A total of 195 marine fungal strains were found in 73 samples from Haikou coastal regions. Isolations from various habitats were shown in Table 1. 106 strains of fungi were isolated from the west coast of Haikou (designated as XB-1 to XB-106); 36 strains from the Nandu River Estuary habitats (named after NE-1 to NE-36); and 53 strains from the YanFeng Town mangrove habitats (labeled with YM-1 to YM-53).

195 marine fungal strains belonged to 46 families, 84 genera, 142 species, the strains mostly belonged to Ascomycota, Basidiomycota and Zygomycota based on ITS rRNA gene analysis (Additional file 1: Table S1; Additional file 3: Figure S1), The Aspergillus, Penicillium, Trichoderma and Glioderma were preponderant fungus. All the fungal ITS rRNA gene sequences showed from 100 to $96 \%$ identity with the existing sequences of NCBI database (Additional file 1: Table S1), These implied that different habitat of marine environment has rich marine fungi and showed abundant biological diversity.

\section{Antibacterial and antitumor activity of the fermentation product of marine fungi}

Antibacterial and anticancer cell activity of marine fungi was shown in Additional file 2: Table S2. 17 strains showed no inhibitory effect on the four indicator bacteria or Melanoma cells B-16, accounting for $8.72 \%$ of the total isolates. The associations of inhibition effects and different habitats were presented in Table 2. The results also indicated that the marine fungi isolated from the three habitats have a wide range of biological activities.

195 Fungi isolated from three habitats can be divided into 4 clusters on the basis of the inhibition acitivity of the pathogenic bacteria and tumor cells (Fig. 3). Additional file 3: Figure S1 and Table 2 showed that the fungi of the cluster 3 had strongest antibacterial activity on S. aureus, P. aeruginosa, K. pneumoniae, than those of other clusters. However, the strains of cluster 1 appeared to be more effective on the Melanoma cells B-16 and E. coli than those of other clusters. The results of Table 2 and Additional file 3: Figure S1 also indicated that the strains separated from breach habitat in West Coastal of Haikou had the strongest antitumor activity, while the isolations of the mangrove forest habitats had the weakest antitumor activity. Nevertheless the fungi isolated from the mangrove forest habitats exhibited the strongest antibacterial activity, while the isolations from the estuarine habitats of Nan Dujiang River showed the weakest antibacterial activity. 
Table 2 The associations between inhibition effects of marine fungi and different habitats

\begin{tabular}{|c|c|c|c|c|c|c|c|c|c|c|}
\hline & \multicolumn{2}{|c|}{ S. aureus } & \multicolumn{2}{|c|}{ K. pneumoniae } & \multicolumn{2}{|c|}{ P. aeruginosa } & \multicolumn{2}{|l|}{ E. coli } & \multicolumn{2}{|l|}{ B-16 } \\
\hline & Strains & $\%$ & Strains & $\%$ & Strains & $\%$ & Strains & $\%$ & Strains & $\%$ \\
\hline \multicolumn{11}{|l|}{$X B$} \\
\hline- & 40 & 37.73 & 53 & 50.00 & 50 & 47.17 & 39 & 36.79 & 28 & 26.42 \\
\hline+ & 34 & 32.08 & 25 & 23.58 & 42 & 39.62 & 43 & 40.57 & 8 & 7.55 \\
\hline++ & 28 & 26.42 & 24 & 22.64 & 12 & 11.32 & 20 & 18.87 & 41 & 38.68 \\
\hline+++ & 4 & 3.77 & 4 & 3.77 & 2 & 1.89 & 4 & 3.77 & 29 & 27.35 \\
\hline \multicolumn{11}{|l|}{$\mathrm{NE}$} \\
\hline- & 13 & 36.11 & 23 & 63.89 & 16 & 44.44 & 19 & 52.78 & 10 & 27.78 \\
\hline+ & 15 & 41.67 & 10 & 27.78 & 17 & 47.22 & 13 & 36.11 & 5 & 13.89 \\
\hline++ & 6 & 16.67 & 1 & 2.78 & 3 & 8.33 & 1 & 2.78 & 20 & 55.56 \\
\hline+++ & 2 & 5.56 & 2 & 5.56 & 0 & 0 & 3 & 8.33 & 1 & 2.78 \\
\hline \multicolumn{11}{|l|}{ YM } \\
\hline- & 5 & 9.43 & 14 & 26.42 & 20 & 37.74 & 17 & 32.08 & 34 & 64.15 \\
\hline+ & 21 & 39.62 & 16 & 30.19 & 11 & 20.75 & 20 & 37.74 & 10 & 18.87 \\
\hline++ & 22 & 41.51 & 17 & 32.08 & 17 & 32.08 & 13 & 24.53 & 7 & 13.21 \\
\hline+++ & 5 & 9.43 & 6 & 11.32 & 5 & 9.43 & 3 & 5.66 & 2 & 3.77 \\
\hline \multicolumn{11}{|l|}{ Total } \\
\hline- & 58 & 29.74 & 90 & 46.15 & 86 & 44.1 & 75 & 38.46 & 72 & 36.92 \\
\hline+ & 70 & 35.9 & 51 & 26.15 & 70 & 35.9 & 76 & 38.97 & 23 & 11.79 \\
\hline++ & 56 & 28.82 & 42 & 21.54 & 32 & 16.41 & 34 & 17.44 & 68 & 34.87 \\
\hline+++ & 11 & 5.64 & 12 & 6.15 & 7 & 3.59 & 10 & 5.128 & 32 & 16.41 \\
\hline
\end{tabular}

"-" bacteriostatic circle diameter $<6 \mathrm{~cm}$ or $\mathrm{IC}_{50}>500 \mu \mathrm{g} / \mathrm{mL}_{;}$"+" $6 \mathrm{~cm} \leq$ this bacteriostatic circle diameter $<10 \mathrm{~cm}$ or $250 \mu \mathrm{g} / \mathrm{mL} \leq \mathrm{IC}{ }_{50}<500 \mu \mathrm{g} / \mathrm{mL} ; "++$ "

$10 \mathrm{~cm} \leq$ this bacteriostatic circle diameter $<15 \mathrm{~cm}$ or $100 \mu \mathrm{g} / \mathrm{mL} \leq \mathrm{IC}_{50}$ ? $<250 \mu \mathrm{g} / \mathrm{mL} ; “+++$ " bacteriostatic circle diameter $\geq 15 \mathrm{~cm}$ or $\mathrm{IC} \mathrm{C}_{50} \leq 100 \mu \mathrm{g} / \mathrm{mL}$

For further analysis, 137 combination results of inhibition activity were found (showed in Fig. 4). It means that 195 fungi can be classified into 137 groups with different biological activities. It is also suggested that the three different habitats are rich in species diversity of marine fungi.

\section{Discussion}

Fungal biodiversity assessments are essential for exploring diversity from not only the biogeographical perspective, but also the view of bioactive secondary metabolites, which help to establish conservation policies Ding et al. (Ding et al. 2011; Duarte et al. 2012). Diversity of fungi has been studied from various habitats including seawater, coastal waters, deep-sea sediments, hypersaline waters, mangroves, salt marshes, and hydrothermal vents (Overy et al. 2014). As is known to all, the coastal region is a dynamic, self-sustained system with biodiversity, meanwhile different marine fungi produced various metabolites which have wide applications in pharmaceutics (Gerwick and Fenner 2013). The aim of this study was to investigate fungal diversity from various marine habitats. This study showed that the secondary metabolites produced by fungi in different coastal habitats had different strength biological activity.

Mangrove habitats are a type of intertidal wetland ecosystems, which are sensitive to global climate change. This is a semi open system, due to tides rise and fall, the environment changes frequently, mangrove plants are deciduous, so mangrove habitats contain abundant organic carbon which allows microbes to thrive inalo (Departamento et al. 2012; Azman et al. 2015). Mangrove sediments are characteristic of strong reduction, low $\mathrm{pH}$, high salinity, nutrient rich, etc., which have rich resources in microbe (Andreote et al. 2012). K-B experiments showed that fungi isolation from the mangrove habitats had strongest antibacterial activity. The reason for this may be due to the intense competition between species, which evolved to secrete substances with high antibacterial activity inhibiting the growth of other strains. Zhang (2013) analyzed the literature on active ingredient of mangrove fungi in China, finding that there are nine compounds separated from fungi of mangrove forests in Hainan having antibacterial activity. This suggests that mangrove habitats are rich in fungi with bacteriostatic activity. 


\section{Clusters}

Input (Predictor) Importance

$\square 1.0 \square 0.8 \square 0.6 \square 0.4 \square 0.2 \square 0.0$

\begin{tabular}{|c|c|c|c|c|}
\hline Cluster & 1 & 3 & 2 & 4 \\
\hline \multicolumn{5}{|l|}{ Label } \\
\hline \multicolumn{5}{|l|}{ Description } \\
\hline Size & \begin{tabular}{|}
$39.0 \%$ \\
$(76)$
\end{tabular} & $\begin{array}{r}27.2 \% \\
(53)\end{array} \mid$ & $\begin{array}{r}18.5 \% \\
(36)\end{array}$ & $\begin{array}{r}15.4 \% \\
(30)\end{array}$ \\
\hline \multirow[t]{6}{*}{ Inputs } & $\begin{array}{c}\text { Habitat } \\
1(100.0 \%)\end{array}$ & $\begin{array}{c}\text { Habitat } \\
3(100.0 \%)\end{array}$ & $\begin{array}{c}\text { Habitat } \\
2(100.0 \%)\end{array}$ & $\begin{array}{c}\text { Habitat } \\
1(100.0 \%)\end{array}$ \\
\hline & $\stackrel{\mathrm{B}}{2.22}$ & $\underset{0.57}{\stackrel{B}{7}}$ & $\stackrel{\mathrm{B}}{1.33}$ & $\stackrel{\mathrm{B}}{0.30}$ \\
\hline & $\begin{array}{c}\mathrm{K} \\
1.09\end{array}$ & $\stackrel{K_{1.28}}{ }$ & $\underset{0.50}{K}$ & $\begin{array}{c}\mathrm{K} \\
0.10\end{array}$ \\
\hline & $\stackrel{\mathrm{S}}{1.20}$ & $\stackrel{S}{S}$ & $\begin{array}{c}S \\
0.92\end{array}$ & $\begin{array}{c}S \\
0.27\end{array}$ \\
\hline & $\stackrel{P}{P}$ & $\stackrel{P}{P}$ & $\stackrel{P}{P}$ & $\stackrel{P}{P}$ \\
\hline & ${ }_{1.07}^{E}$ & $\stackrel{\mathrm{E}}{0.98}$ & 0.61 & $\underset{0.53}{E}$ \\
\hline
\end{tabular}

Fig. 3 Clustering analysis of fungi with different biological activity fungi (B is Melanoma cells B-16, S is S. aureus, P is P. aeruginosa, K is K. pneumoniae, E is E. coli)

The MTT assay showed that the strains separated from beach habitats had the strongest antitumor activity. It is probable that along the west coast, there is no sewage flowing into the sea, which contained lots of harmful substances hazardous waste, include in the vicinity of the Haikou Port and new port, household garbage and other harmful substances accumulated in the habitats, which makes fungi adapt to the harsh environments.

\section{Conclusions}

195 strains of marine fungi were isolated and purified from the three coastal habitats (i.e., beach habitats, estuarine habitats and mangrove habitats). K-B method and MTT method were applied to evaluate the antibacterial and antitumor cell activity for secondary metabolites of marine fungi. The experiment results showed that fungi isolation from the mangrove habitats had the strongest 


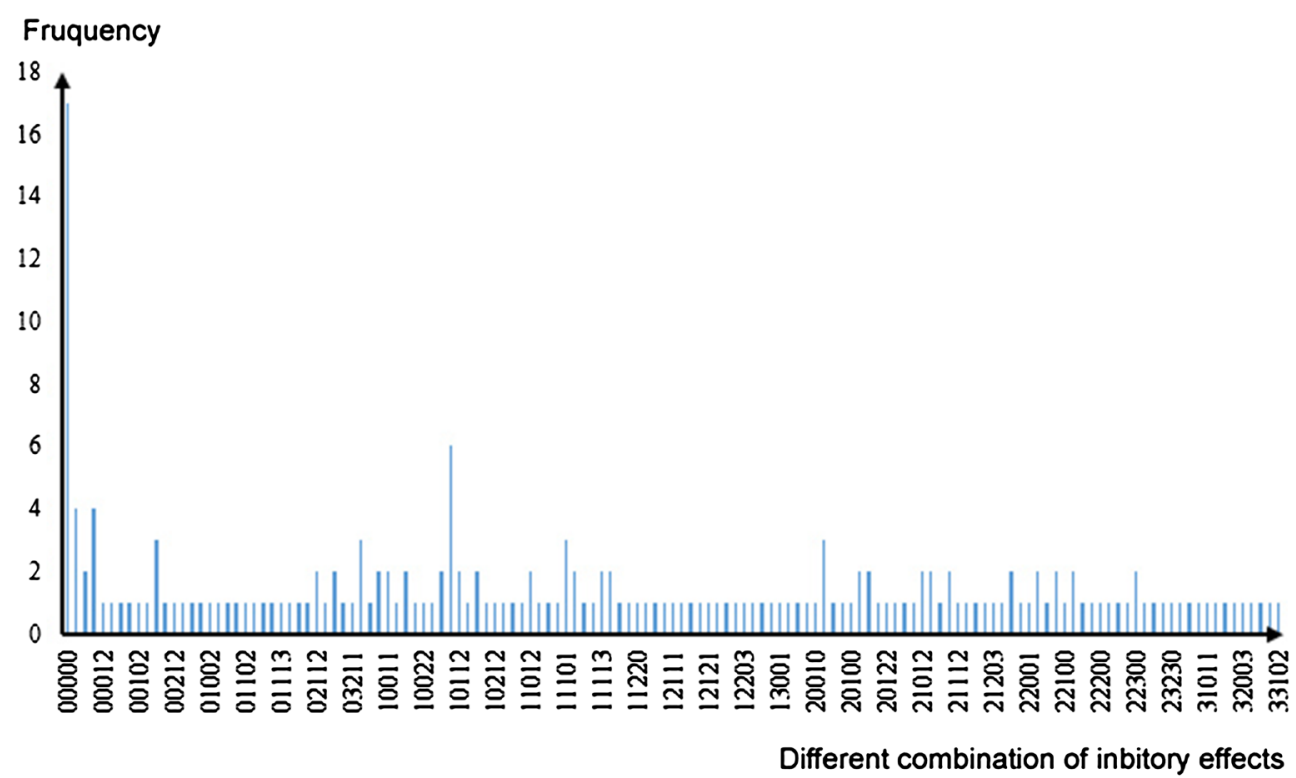

Fig. 4 The frequency of different combination of inhibition activity

antibacterial activity, while strains separated from beach habitats had the strongest antitumor activity. Further analysis indicated that 195 fungal strains fell into 137 groups of different combination of inhibitory activity. This work may help to broaden our understanding of the fungal diversity in various marine habitats with different biological activity biological activity, and offer some useful experiences to select fungi for producing bioactive compounds from various marine habitats.

\section{Additional files}

Additional file 1: Table S1. Phylogenetic affiliations of culturable fungi based on of ITS rDNA gene sequences.

Additional file 2: Table S2. The inhibitory effects of marine fungi on four strains of pathogenic bacteria and melanoma cells B-16.

Additional file 3: Figure S1. Phylogenetic tree based on ITS rRNA genes from three coastal habitats.

\section{Authors' contributions}

SLZ carried out the design and performed majority of the experimental work. MW participated in data collection and regulation. YYL and HGZ performed a part of the experimental work. QF contributed to the statistical process and writing the manuscript. All authors read and approved the final manuscript.

\section{Author details}

1 Key Laboratory of Tropical Diseases and Translational Medicine of The Ministry of Education, Hainan Medical College, Haikou 571199, China. ${ }^{2}$ Department of Aquatic Science and Technology, Jiangsu Agri-animal Husbandry Vocational College, Taizhou 225300, China.

\section{Acknowledgements}

The authors acknowledge the financial support provided by the National Natural Science Foundation of China, No. 81560484

\section{Competing interests}

The authors declare that they have no competing interests.

Received: 9 June 2016 Accepted: 4 November 2016

Published online: 14 November 2016

\section{References}

Andreote FD, Jimenez DJ, Chaves D, Dias ACF, Luvizotto DM, Dini-Andreote F, Fasanella C, Lopez MV, Baena S, Taketani R, de Melo IS (2012) The microbiome of Brazilian mangrove sediments as revealed by metagenomics. PLOS ONE 7:e38600. doi:10.1371/journal.pone.0038600.g001

Azman AS, Othman I, Velu SS, Chan KG, Lee LH (2015) Mangrove rare actinobacteria: taxonomy, natural compound, and discovery of bioactivity. Front Microb 6:856-871. doi:10.3389/fmicb.2015.00856

Blunt JW, Copp BR, Keyzers RA, Munro MH, Prinsep MR (2014) Marine natural products. Nat Prod Rep 31:160-258. doi:10.1039/c3np70117d

Danovaro R, Pusceddu A (2007) Biodiversity and ecosystem functioning in coastal lagoons: does microbial diversity play any role? Estuar Coast Shelf Sci 75:4-13

Departamento DM, Universidade FP, Cidade U, Recife PE (2012) Diversity of leaf endophytic fungi mangrove plants of northeast brazil. Braz J Microb 43:1165-1173

Ding B, Yin Y, Zhang F, Li Z (2011) Recovery and phylogenetic diversity of culturable fungi associated with marine sponges Clathrina luteoculcitella and Holoxea sp. in the South China Sea. Mar Biotech 13:713-721. doi:10.1007/ s10126-010-9333-8

Drew WL, Richardl O, Sherris JC (1972) Reliability of the Kirby-Bauer disc diffusion method for detecting methicillin-resistant strains of Staphylococcus aureus. Appl Microb 24:240-247

Duarte K, Santos R, Teresa AP, Freitas AC, Duarte AC (2012) Analytical techniques for discovery of bioactive compounds from marine fungi. TrAC Tren Anal Chem 34:97-110. doi:10.1016/j.trac.2011.10.014

Gerwick WH, Fenner AM (2013) Drug discovery from marine microbes. Microbl Ecol 65:800-806. doi:10.1007/s00248-012-0169-9

Klindworth A, Mann AJ, Huang S, Wichels A, Quast C, Waldmann J, Teeling $\mathrm{H}$, Glockner FO (2014) Diversity and activity of marine bacterioplankton during a diatom bloom in the North Sea assessed by total RNA and pyrotag sequencing. Mar Genom 18:185-192. doi:10.1016/j. margen.2014.08.007 
Massana R, Logares R (2013) Eukaryotic versus prokaryotic marine picoplankton ecology. Environ Microb 15:1254-1261. doi:10.1111/1462-2920.12043

Miloslavich P, Díaz JM, Klein E, Alvarado JJ, Díaz C, Gobin J, Briones EE, CruzMotta JJ, Weil E, Bastidas JC, Robertson R, Zapata F, Martín A, Castillo J, Aniuska K, Ortiz M (2010) Marine biodiversity in the Caribbean: regional estimates, distribution patterns. PLoS ONE 5:e11916. doi:10.1371/journal. pone.0011916.g001

Overy DP, Bayman P, Kerr RG, Bills GF (2014) An assessment of natural produc discovery from marine (sensu strictu) and marine-derived fungi. Mycology 5:145-167. doi:10.1080/21501203.2014.931308

Rämä T, Nordén J, Davey ML, Mathiassen GH, Spatafora JW, Kauserud H (2014) Fungi ahoy! Diversity on marine wooden substrata in the high North. Fungal Ecol 8:46-58. doi:10.1016/j.funeco.2013.12.002
Richards TA, Jones MD, Leonard G, Bass D (2012) Marine fungi: their ecology and molecular diversity. Ann Rev Mar Sci 4:495-522. doi:10.1146/ annurev-marine-120710-100802

Rivera KG, Seifert KA (2011) A taxonomic and phylogenetic revision of the Penicillium sclerotiorum complex. Stud Mycol 70:139-158. doi:10.3114/ sim.2011.70.03

Singh P, Raghukumar C, Verma P, Shouche Y (2012) Assessment of fungal diversity in deep-sea sediments by multiple primer approach. World Microbiol Biotechnol 28:659-667. doi:10.1007/s11274-011-0859-3

Zhang ZH (2013) Research advances in Biodiversity of Mangrove Fungi. Chin J Trop Crops 34:1617-1624

\section{Submit your manuscript to a SpringerOpen ${ }^{\odot}$ journal and benefit from:}

- Convenient online submission

- Rigorous peer review

- Immediate publication on acceptance

- Open access: articles freely available online

- High visibility within the field

- Retaining the copyright to your article 